$5-11-2008$

\title{
Review - Constitutional Conscience: The Moral Dimension of Judicial Decision, by H. Jefferson Powell, and How Judges Think, by Richard A. Posner
}

\author{
Paul Horwitz \\ University of Alabama - School of Law, phorwitz@law.ua.edu
}

Follow this and additional works at: https://scholarship.law.ua.edu/fac_working_papers

\section{Recommended Citation}

Paul Horwitz, Review - Constitutional Conscience: The Moral Dimension of Judicial Decision, by H. Jefferson Powell, and How Judges Think, by Richard A. Posner, (2008).

Available at: https://scholarship.law.ua.edu/fac_working_papers/520

This Working Paper is brought to you for free and open access by the Faculty Scholarship at Alabama Law Scholarly Commons. It has been accepted for inclusion in Working Papers by an authorized administrator of Alabama Law Scholarly Commons. 


\section{THE UNIVERSITY OF ALABAMA SCHOOL OF LAW}

REVIEW

CONSTITUTIONAL CONSCIENCE: THE MORAL DIMENSION OF JUDICIAL DECISION By H. JEFFERSON POWELL and HOW JUDGES THINK By RICHARD A. POSNER

PAUL HORWITZ

This paper can be downloaded without charge from the Social Science Research Network Electronic Paper Collection: http://ssrn.com/abstract=1131406 


\title{
HOW JUDGES THINK \\ BY RICHARD A. POSNER
}

\section{CONSTITUTIONAL CONSCIENCE: THE MORAL DIMENSION OF JUDICIAL DECISION BY H. JEFFERSON POWELL}

\author{
Reviewed by Paul Horwitz \\ Associate Professor, University of Alabama School of Law
}

What do we want of our judges? And, whatever we may want, want can we reasonably expect to get from them? For all that these questions bedevil us, we rarely ask them so directly. The first question has featured prominently in every contested federal judicial nomination and every presidential campaign since America met Robert Bork, but the public and politicians generally neglect the second question. Constitutional theorists often act as if the role and limitations of judges are a mere nuisance; surely, they will suggest sotto voce, the best judge is the one who most closely tracks my own thinking and institutional constraints be damned.

Happily, two recent developments in legal scholarship have led us to consider these questions more closely and more clearly. The ever-widening gyre of law and economics and its cousin, behavioral law and economics, has led an increasing number of scholars to put the judge, with all his motivations, incentives, and cognitive limitations, in the spotlight. And a small but promising band of legal scholars, influenced by the flourishing study of virtue ethics elsewhere in the academy, has begun to consider the role of virtue in judging.

These contrasting approaches are on vivid display in two rich new books. H. Jefferson Powell's Constitutional Conscience: The Moral Dimension of Judicial Decision takes a page from virtue ethics in offering an expansive and ruminative vision of the ethical virtues and vices that characterize the judge in a constitutional case. In How Judges Think, Judge Richard A. Posner brings his economist's toolkit, supplemented as usual by a variety of disciplinary adjuncts and a bracing dose of pragmatism, to many of the same questions, although his object is somewhat different from Powell's and his conclusions are strikingly so.

Powell begins his exploration of the role and duty of the constitutional judge in territory that has been oft-explored but still leaves much to be discovered and discussed: John Marshall's opinion in Marbury v. Madison. In mustering his arguments for judicial review, Marshall asked of the Constitution:

Why otherwise does it direct the judges to take an oath to support it? ... How immoral to impose it on them, if they were to be used as the instruments, and the knowing instruments, for violating what they swear to support! ... 
Why does a judge swear to discharge his duties agreeably to the constitution of the United States, if that constitution forms no rule for his government? ... If such be the real state of things, this is worse than solemn mockery. To prescribe, or to take this oath, becomes equally a crime.

This passage has been criticized and sometimes mocked almost since its inception; in his famous dissenting opinion in Eakin v. Raub in 1825, Judge Gibson wrote that the oath is "taken indiscriminately by every officer of the government, and is designed rather as a test of the political principles of the man, than to bind the officer in the discharge of his duty." More recently, Judge Posner, who serves as a foil in Powell's book, called the oath "a loyalty oath rather than a direction concerning judicial discretion."

Thankfully, and quite rightly, Powell, reaching through the mists of history to a time in which oaths had far-reaching consequences based on a wider sense of honor and virtue at large in the society, sees something more to it than that. Marshall's appeal to the oath, he writes, suggests a "juxtaposition of the judiciary's governmental role and the judge's personal conscience." Thus, the practice of judicial review is related not only to the broader constitutional structure that demands it, but "flows as well from the judge's individual obligations as a moral actor." The inescapable aspect of moral obligation at the center of the judge's duties thus "implies a closer connection than is sometimes acknowledged between how we understand constitutional law and how individual judges understand the moral circumstances in which they carry out their duties."

From this departure point, Powell derives two central themes. The first is that it should be possible to derive a set of standards for evaluating the work of the judge or Justice in moral or ethical terms. The second is that we can understand constitutional law from within this ethical perspective as an attempt to establish a fair process of resolving inevitable political and social conflicts without expecting, or demanding, "consensus or even broad agreement on many issues." What we think of as the actual practice of constitutional law - the "game" that Justice Holmes famously observed he must "play by the rules," rather than simply "doing justice" - is the suite of acceptable and traditionally well-worn forms of arguments that constitute that practice. These practices involve much that is careful, precise, and "technical" about reading the Constitution; but even a goodfaith attempt to reach a constitutional ruling on this basis ultimately may drive us "beyond the realm of professional expertise and algorithmic reasoning" into "a sphere in which intellectual and moral integrity are essential." On this basis, he again presses his central point: the elements of good (and bad) faith that we can derive from an examination of sound constitutional judging simultaneously make evident that constitutional judges enter "the realm of moral obligation to which Marshall appealed in his discussion of the judicial oath," and provide us with a metric to see how well or poorly they traverse that territory.

What are the virtues that constitute a moral constitutional judge, in Powell's view? It is not unfair to say that they are few, and fairly abstract, although Powell is a skilled exegete and makes the most of them. The first is good faith: the belief that the 
Constitution has an intelligible meaning, and the will to discern and honor that meaning as best as one can. Second, given the open spaces in that document, judges must display candor, by which Powell means a willingness to fully and transparently express in words the judge's sincere effort to grapple with the meaning of the Constitution, and integrity "the virtue of seeking in any given situation that interpretation of the Constitution that honestly seems to the interpreter the most plausible resolution of the issues in the light of the text and constitutional tradition." Powell's description of the remaining virtues is often more substantive than simply procedural or even ethical as such. He describes humility as being, not about the judge's own frailties, but about her willingness to accept that the Constitution leaves some divisive issues to be settled by the political process; and he names as a constitutional virtue "acquiescence," a judge's willingness to accede to long-standing precedents of constitutional law and practice even if she might not reach those conclusions independently. Without these virtues, Powell bluntly concludes, "American constitutionalism is a fraud."

Powell concludes, as he must after such a stirring but distinctly romantic view of the judge's task, and of our own shared duty to "live out in the political and moral life of the Republic at large the virtues which the Constitution expects of its official interpreters," by observing that his ideals "can be accused of fantasy, a failure to see that the political enjoys priority in a much harsher sense than I have conceded, that there is not and cannot be anything other than the agonistic struggle of political preferences."

That is as good a place as any to say: Enter Richard Posner. Powell would drape the figure of Lady Justice in new and glorious robes, albeit robes of ancient design. Given his druthers, Posner would criticize the cut of Justice's robes, scoff that they aren't warm enough to have any useful function, and digress to note that the taboo against nudity is itself a historically contingent and only locally applicable social norm. (Seriously. Doubters may consult the index entries on "nudity" in Posner's Sex and Reason.)

Posner begins by doubting that most judges themselves are especially reliable authorities about the judge's role. They are all too apt to spout "the loftiest Law Day rhetoric," and can be "cagey, even coy, in discussing what they do. They tend to parrot an official line about the judicial process ...., and often to believe it, though it does not describe their actual practices." Like their brethren in the wider legal profession, they have developed "a mystique" about judging "that exaggerates not only the professional's skills but also his disinterest. Judges have been doing this for thousands of years and have become quite good at it."

Posner will have none of this. Judges are not, he says, "moral or intellectual giants (alas), prophets, oracles, mouthpieces, or calculating machines. They are all-too-human workers, responding as other workers do to the conditions of the labor market in which they work." They are not "legalists" in a strict sense, working at formal proofs like so many logicians at a blackboard: belief in legalism as the solution to the judicial puzzle is "the falsest of false dawns." Judges are "political," a loaded term by which he simply means that their decisions on divisive moral issues that "cannot be resolved by expert analysis, let alone by conventional reasoning," perforce must be influenced by a range of 
factors including ideology, background, personal preference, and so on. They are "occasional legislators" who use these and other factors to reach decisions in the open spaces afforded them by statutes and by a 200-year-old Constitution of broad reach and limited clarity.

Above all, in his view, they are "constrained pragmatists": "rule pragmatists" who decide cases with regard to their consequences, with all the potentially free-floating policy considerations that entails, but who are subject to a host of internal and external constraints on their decision-making. A constrained pragmatist judge may well decide cases in "legalist" fashion, but she will do so because legalism can have systemic beneficial consequences, not because legalism is compelled in some deeper sense. Like Holmes, Posner's constrained pragmatist "must play by the rules of the judicial game, just like other judges."

With barely restrained glee, Posner unapologetically warns readers that they will have to "brace themselves" for such analytic jargon as Bayesian decision theory, "reversal aversion," "utility function," and "agency costs." Although judges might not think in those terms, he emphasizes that "we must consider what judges want. I think they want the same basic goods that other people want, such as income, power, reputation, respect, self-respect, and leisure." Indeed, much of his book is given over to a consideration of the elements that make up the "judicial utility function" - a congeries of personal, psychological, broadly economic, and other factors that influence both the supply and demand curve for judges and the way they work.

He does not disdain the kinds of legal craft constraints that surely form a large part of Powell's picture of the judge. These craft considerations are an important part of the judge's makeup and make up a significant part of his pleasure in the job at hand. Neither, though, does he romanticize legal craft or believe that it offers much clarity or resolution in difficult cases. The law student, he writes, must learn all the conventional techniques of the lawyer - "en route to transcending them. But transcend them (or at least begin the process of transcending them) he must." He does not mock reason, but he believes firmly in its limits, particularly in constitutional law, whose open-endedness and emotional content can turn reason into a mere patina, providing a gloss on "reasons" that reason knows not: "A Supreme Court Justice - however questionable his position in a particular case might seem to be - can, without lifting a pen or touching the computer keyboard, but merely by whistling for his law clerks, assure himself that he can defend whatever position he wants to take with enough professional panache to keep the critics at bay."

It is no labor to review a writer as eminently quotable as Posner. Here he is disdaining the "committee of lawyer aristocrats" that make up the Court: "Cocooned in their marble palace, attended by sycophantic staff, and treated with extreme deference wherever they go, Supreme Court Justices are at risk of acquiring an exaggerated opinion of their ability and character." He makes similarly short work of both Antonin Scalia and Stephen Breyer, neither of whose apologia for their preferred brands of judging he finds persuasive. He derides Anthony Kennedy - in many respects the acme of a Powellian Justice obsessed with the moral character of judging - as a mystic and messiah manqué in 
judges' robes, and adds, of his opinion in Gonzales v. Carhart, "What does it tell us about the commitment to legalism of the four most conservative Justices of the Supreme Court that they should have joined such a wild opinion?" Under his pen fall Henry Hart, Erwin Griswold, the former President of the Israeli Supreme Court, the liberal law professors who contested the Solomon Amendment in Rumsfeld v. FAIR, and whole legions besides.

The only difficult task for the reviewer is threading a path through a book that is strewn with divagations on topics as diverse as the rules of baseball as they apply to Chief Justice Roberts's infamous "umpire" metaphor, the citation of foreign law, and the elasticity of salary incentives for judges. But his ending point is clear enough. However much judges and others may wish to deny it, there is an unavoidable personal and political element in their decisions on the most contested areas of law, especially constitutional law. Although even constrained pragmatism is no antidote, it can at least encourage us to reach our decisions, and analyze the virtues of those decisions, in a cleareyed way that takes into account all of the internal and external factors that drive them.

There is no doubt that Powell and Posner differ in their approaches and at least some of their conclusions. The indexes to their books tell the story well. Posner observes early on that a classic text on American judges lacks index entries for "politics" or "ideology." Posner's own book likewise lacks entries for words such as "oath," "honor," and "duty," while Powell neglects a raft of social and economic terms that might have added some leavening realism to his rapture. Surprisingly, both lack an entry for "Weber, Max." This is a shame (and, where Posner is concerned, a shock), because both might have done well to consider the extent to which either the constitutionally virtuous judge or the brilliant and wide-ranging, if constrained, pragmatist judge has much of a role left to play in an increasingly routinized, bureaucratic, and disenchanted age.

Despite their wildly divergent paths, though, Posner and Powell in fact share many common ties. Both, for example, share interesting and important views on how we might reform legal education - in Powell's case, to focus more on "how constitutional questions can be resolved with integrity and their resolution expressed with clarity," and in Posner's to master conventional legal skills and then move beyond them and focus on the actual underpinnings of judicial decision. And although Posner might reject Powell's approach as tending towards the "moral vanguardism" of a Justice Kennedy, he repeatedly emphasizes that some of the most important constraints on the judicial task are, "first, the desire for self-respect and for respect from other judges and legal professionals generally, which a judge earns by being a good judge, and, second (and closely related), the intrinsic satisfactions of judging, which usually are greater for a good judge than for a bad one." So even a Posnerian judge may have recourse to the kinds of quasi-moral constitutional "virtues" that are at the heart of Powell's work.

Both also share some of the same blind spots. Foremost among them is their regrettable focus on federal appellate judges, particularly the Justices of the Supreme Court. To be sure, as Powell writes, the Court "has by a very large margin the loudest institutional voice in constitutional debate"; and it often writes in the most open margins of the law, rendering it a fit subject for Posner's thesis. But if we are to take seriously the 
importance of virtuous judging, in Powell's case, or judging as a mixture of subtle constraints and motivations, in Posner's case, and of good and bad faith judging in both writers' case, perhaps it would be better to focus on judges whose every action is not in the public spotlight. Those judges may fall prey more easily to the temptation to act in bad faith despite the loose shackle of precedent - especially since, as Posner notes, most lower court decisions are no longer subject to serious review. Both writers, for example, have something to say about race and Brown v. Board of Education. But if they are to think seriously about the courts' role and constraints in this area, and to examine whether judges act in good faith in such a controversial field, perhaps they would have been better off examining what the district courts and the old Fifth Circuit did in implementing, extending, and, in the case of many district courts, resisting Brown. Powell and Posner's approach is like asking about the honesty of the constabulary by examining the probity of the Chief of Police, instead of looking at the lowly, lonely, constantly tempted desk sergeant in the evidence room of a local police precinct.

My head is with Posner. Too much is missing from Powell's account. Nowhere in his book do we find a serious accounting for the many real-world factors in which judicial decision making takes place: the role of law clerks as canned reasoners for judges who perforce need do little reasoning of their own; the extent to which judging is a social and collegial process rather than the purely solitary and deliberative act of a cloistered monk in a cell; the host of human motivations and limitations that drive and hem in a judge and make unlikely any effort to set down a reliable instruction manual for any would-be judicial Hercules; and any number of broader institutional factors that might add depth to his romantic view of the judiciary. His constant refrain that his picture of constitutional virtue must be true because "much of what we do and say and do in constitutional interpretation" would otherwise be meaningless, a "solemn mockery," begs the question: What if it is? You cannot prove God's existence by saying that life would be bleak if God did not exist; no more can Powell prove the necessity of his approach by arguing that it would be depressing to think otherwise. Posner writes that "for judges to acknowledge even just to themselves the political dimension of their role would open a psychologically unsettling gap between their official job description and their actual job"; Powell's apparent response is, then let us not acknowledge it. But that is not a proof; he is mixing his "is" and his "ought."

And one might pick a number of fights with the substantive "virtues" Powell has selected, and some of the vices he deplores. His vision of "acquiescence" is in more tension than he acknowledges with the role of the oath, which requires a judge in good faith to exercise some independent judgment about what the Constitution requires; to be sure, precedent plays a part, but a conscientious judge cannot utterly displace his own obligation finally to make a judgment of his own. His privileging of what he calls "the priority of the political" - that is, his view that judges must respect the priority of decision making in the public and political realm rather than in the courts - may be an unquestionable good as a default position in constitutional judging, but that does not make it a virtue in a deeper ethical sense. And his attack on "instrumentalist" judges such as Posner is flatly unconvincing in light of the fuller picture Posner himself paints in How Judges Think. As Posner points out, there is no reason why pragmatism cannot be 
considerably bounded and constrained, both by the Constitution itself and by the host of traditions and practices in which it is embedded.

Posner has his flaws as well: his non-formalist position on foreign judicial materials, which seems to boil down to "read but don't cite," is close to incoherent, and he might have done well to look for examples of legal and judicial virtue beyond the canonical and unrepresentative Holmes, as Powell does with a $19^{\text {th }}$ century legal opinion by Attorney General Amos Akerman. But as a description of what judges do and what they are likely to continue to do in anything other than the best of all possible worlds, Posner easily wins this match on points.

But my heart, I must confess, lies substantially, although not entirely, with Powell. Posner, it would seem, regards naivete as a cardinal sin: he would rather explain (and revel in) judges' limits than seek even a tentative path beyond them. That's unfortunate. Virtue ethics' status as a growth stock in the academy has slowly but surely fostered some important efforts to think about virtue and its relationship to the judicial task, as exemplified in recent treatments by Lawrence Solum, Suzanna Sherry, and Daniel Farber. These early efforts are still more shallow than deep; they are still largely nostrums - more "Law Day rhetoric" - rather than deep treatments of the issue. But they are, I believe, the right path. In that sense, Powell's book, with its yearning and eloquent reach in that direction, is a good step forward.

But much more than idealism is required. A paean to the judicial virtues will have little impact, in light of the much more solid evidence mustered by Posner, without a substantial shift in the culture surrounding it - if not the whole culture, then at least the legal culture. If we are to have the judges Powell wants, honoring and inhabiting the kinds of virtues he lauds, we are unlikely to get them piecemeal. We need generally to recapture a sense of public and private virtue that has largely been lost in the face of the rationalistic and disenchanted spirit of our age - a spirit, it should be said, that is not without virtues of its own, as it were. We need to recapture and adapt a sense of the virtues to our own time, and to internalize that sense in a way that can actually serve as a meaningful constraint on judicial action. Powell, is right, I think, to hearken back to Marbury's invocation of the oath, for surely obedience to the oath requires something more than shallow loyalty. For those who take it seriously, every judicial act should partake of a quality of commitment and obligation that is distinctly moral; the judge should constantly ask herself whether she is acting in accord with the deeper sense of honor that she puts at stake by taking the oath. But honor, and the importance of the oath, are largely obsolete values today, and it will take considerable imaginative work to retrieve them.

We shouldn't fool ourselves: however Edenic Powell's world may be, it is not the world we live in, and likely never was. We live in Posner's world, with all its human imperfection. We should not forget it. No single judicial approach, whether one of legalism or loose constructionism, and no lofty Law Day rhetoric, can bring us out of it. But we can wish for Powell's world, and perhaps take small steps to make it our own. To bring the judicial virtues to life, however, we will have to take stock honestly of the 
world we actually live in. Ironically, to get to Powell's virtue, and the virtue of judges and lawyers at the center of Powell's affections, like Marshall and Akerman, we may need more than a little dose of Holmes and Posner and their acid bath. We can and should emulate Powell, but we ought to make sure that at least a small corner of our minds has learned well and retained Posner's lessons. 